\title{
The estrogen-regulated anterior gradient 2 (AGR2) protein in breast cancer: a potential drug target and biomarker
}

\author{
Michael L Salmans' ${ }^{1}$ Fang Zhao² and Bogi Andersen*1
}

\begin{abstract}
Initially discovered as an estrogen-responsive gene in breast cancer cell lines, anterior gradient 2 (AGR2) is a developmentally regulated gene belonging to the protein disulfide isomerase (PDI) gene family. Developmentally, AGR2 is expressed in the mammary gland in an estrogen-dependent manner, and AGR2 knockout and overexpression mouse models indicate that the gene promotes lobuloalveolar development by stimulating cell proliferation. Although AGR2 overexpression alone seems insufficient for breast tumorigenesis in mice, several lines of investigations suggest that AGR2 promotes breast tumorigenesis. Overexpression of AGR2 in several breast cancer cell lines increases cell survival in clonogenic assays and cell proliferation, whereas AGR2 loss of function leads to decreased cell cycle progression and cell death. In addition, AGR2 was shown to promote metastasis of breast epithelial cells in an in vivo metastasis assay. As a PDI, AGR2 is thought to be involved in the unfolded protein response that alleviates endoplasmic reticulum stress. Since cancer has to overcome proteotoxic stress due to excess protein production, AGR2 may be one of many pro-survival factors recruited to assist in protein folding or degradation or both. When AGR2 is secreted, it plays a role in cellular adhesion and dissemination of metastatic tumor cells. In breast cancer, AGR2 expression is associated with estrogen receptor (ER)-positive tumors; its overexpression is a predictor of poor prognosis. The AGR2 gene is directly targeted by ER-alpha, which is preferentially bound in tumors with poor outcome. Whereas aromatase inhibitor therapy decreases AGR2 expression, tamoxifen acts as an agonist of AGR2 expression in ER-positive tumors, perhaps contributing to tamoxifen resistance. AGR2 is also overexpressed in a subset of ER-negative tumors. Furthermore, AGR2 expression is associated with the dissemination of metastatic breast cancer cells and can be used as a marker to identify circulating tumor cells and metastatic cells in sentinel lymph nodes. In conclusion, AGR2 is a promising drug target in breast cancer and may serve as a useful prognostic indicator as well as a marker of breast cancer metastasis.
\end{abstract}

\section{Introduction}

The estrogen receptor (ER) is a key regulator of mammary gland development and breast carcinogenesis, regulating pro-proliferative and pro-survival genes in breast epithelial cells. The human anterior gradient 2 (AGR2), one of the many targets of ER, was first discovered as an overexpressed gene in ER-positive breast cancer cell lines $[1,2]$ and has since been shown to be overexpressed in breast cancers and many other adenocarcinomas, including colorectal, esophageal, lung,

\footnotetext{
*Correspondence: bogi@uci.edu

'Departments of Medicine and Biological Chemistry, University of California, Sprague Hall, Room 206, Irvine, CA 92697-4030, USA

Full list of author information is available at the end of the article
}

ovarian, pancreatic, and prostate carcinomas [3-10]. Its overexpression in ER-positive breast cancer is associated with poor prognosis, especially in tumors that escape anti-hormone therapies [11]. AGR2 acts by promoting cell proliferation, cell survival, and metastasis of breast cancer cells $[12,13]$. As ER activation can generate a large influx of gene transcripts, subsequent translation creates stress on the endoplasmic reticulum that the tumor cell must overcome to survive. A member of the protein disulfide isomerase (PDI) family that localizes to the endoplasmic reticulum [14], AGR2 may assist in protein folding and endoplasmic reticulum-assisted degradation (ERAD) of proteins [15]. The ability of ER to activate the $A G R 2$ gene may therefore allow the tumor to resist proteotoxic stress and avoid cell death. In addition, AGR2 is a secreted protein [13] and, as such, may promote breast cancer metastases by regulating the adhesion and 
dissemination of tumor cells. In this review, we discuss the effects of AGR2 expression in breast cancer cells, highlighting its role as a survival factor in response to proteotoxic stress, its function in mediating tumor metastasis, and the molecular pathways that it acts through to control cell proliferation. Targeted inhibition of AGR2 may be useful in breast cancer as it may induce cell death in response to proteotoxic stress, prevent tumor metastasis, and slow the rate of tumor growth.

\section{AGR2 and related family members}

The mammalian anterior gradient proteins, AGR1, AGR2, and AGR3, belong to a family of PDIs, which function in the endoplasmic reticulum to reduce, oxidize, or isomerize disulfide bonds [16]. In addition to having a role in protein folding, PDIs function as molecular chaperones and in the ERAD protein degradation pathway. Outside of the endoplasmic reticulum, PDIs have been described as secreted proteins that function at the cell surface and the extracellular matrix. The specific functions of the AGR2 and AGR3 family members as PDIs are poorly understood. Anterior gradient genes were originally discovered in Xenopus laevis and named for their expression patterns in the anterior region of the dorsal ectoderm during late gastrulation [17]. Xenopus anterior gradient-2 (XAG-2), a secreted cement glandspecific protein, plays a role in the specification of the dorsoanterior ectoderm to cement gland and forebrain fates. AGR2, the human homologue of XAG-2, was first identified as an upregulated gene in the ER-positive MCF-7 breast carcinoma cell line compared with the ERnegative MDA-MB-231 breast carcinoma cell line [1]. $A G R 2$ was one of eight genes that correlated with ER expression and responded to estradiol treatment in MCF-7 cells, an observation that was validated in eight additional breast carcinoma cell lines and primary tumor samples [2]. The correlation between AGR2 expression and ER positivity of breast cancer cell lines and the ability of estradiol to induce its expression suggested the possibility that AGR2 mediates estrogenic actions in normal physiology and breast cancer.

AGR3 was discovered in a proteomics screen for proteins associated with the cell membrane of the ERpositive T-47D and MCF-7 breast carcinoma cell lines [18]. The human AGR2 and AGR3 genes map to chromosome band $7 \mathrm{p} 21.3$ and share $71 \%$ sequence identity $[3,19]$. The two are transcribed from the same DNA strand and are separated by only $60 \mathrm{~kb}$ of sequence. Although the contiguity of AGR2 and AGR3 would suggest that they are co-regulated, the contrary is observed in several cases: in normal mammary gland development, mouse Agr2 is preferentially expressed in comparison with Agr3 during pregnancy, lactation, and involution [20], whereas mouse ovarian cancers express
$A g r 3$, and not $A g r 2$, in ER-negative tumors [21]. In addition, uncoupled expression of AGR2 and AGR3 is observed in multiple prostate cancer cell lines, with preferential expression of AGR2 in most cell lines [22]. However, there are cases in which the two genes are coexpressed, such as MCF-7 cells after treatment with estradiol [23]. The mechanisms underlying differential expression of AGR2 and AGR3 are poorly understood and warrant further investigation.

AGR1 is more commonly known as endoplasmic reticulum protein (ERp) 18/19 because of its functional role as a PDI in the endoplasmic reticulum [24]. Homology analyses revealed high similarity between ERp18/19 and AGR2 and AGR3, providing the previously uncharacterized AGR2 and AGR3 proteins with possible functions as PDIs. Whereas AGR2 and AGR3 have both been linked to breast cancer, AGR1 has not been identified as a breast cancer gene of interest in any bioinformatics study to date. However, it is clear that the role of the AGR1 PDI in normal biological settings provides insights into the possible functions of AGR2 and AGR3 in both normal mammary gland morphogenesis and breast carcinogenesis.

\section{The role of AGR2 in breast cancer}

\section{AGR2 expression in breast cancer is an indicator of poor} outcome

AGR2 was originally described as an overexpressed gene in breast cancer cell lines and later as an overexpressed gene in breast cancer, especially in association with ER positivity [1-3]. The overexpression in breast cancer is clinically relevant as high levels of AGR2 are associated with poor prognosis in ER-positive breast cancer $[11,25,26]$. In contrast to these three studies showing correlation of high AGR2 levels with poor prognosis, a single study analyzing a mixed population of ER-positive and ER-negative tumors reported improved overall survival rates of breast cancer patients who express AGR2. These results, however, may be confounded as the reported survival analysis did not factor in ER status, which has a profound impact on the prognosis [9]. It is possible that the increased survival rate of AGR2expressing tumors may be the result of the improved prognosis conveyed by ER expression. One of the studies associating AGR2 expression with poor prognosis used a cohort of patients that were treated only by mastectomy without adjuvant or hormonal therapy [26], whereas a separate study revealed that tamoxifen treatment has an agonist effect on AGR2 expression that may contribute to treatment failures in ER-positive tumors [11]. These observations indicate that the expression of AGR2 in poor-prognosis tumors may be due to multiple regulatory mechanisms: AGR2 expression can be induced in an ERdependent manner early in tumorigenesis, leading to an 
intrinsic therapeutic resistance, or its expression can be induced in response to anti-hormone treatment, leading to an acquired resistance to therapies. Furthermore, high AGR2 expression is sometimes found in ER-negative breast cancers [3], indicating a different mechanism of upregulation, such as physiological stress [27]. Understanding the regulatory mechanisms that control AGR2 in these situations may shed light on its role in breast cancer, especially the difficult-to-treat cases that exhibit AGR2 overexpression.

Breast tumors can be classified into the basal-like, Her2, luminal A, luminal B, and normal breast-like subtypes on the basis of their intrinsic gene expression profiles [28]. In three independent gene expression data sets [29-31] that classified a total of 1,169 tumors into their respective subtypes, AGR2 is expressed significantly higher in the ER-positive luminal A and B subtypes compared with the ER-negative basal-like, Her2, and normal-like subtypes (Figure 1a), supporting the previously reported overexpression of AGR2 in ER-positive breast cancer. Interestingly, AGR3 is also expressed significantly higher and with the widest range of expression in the luminal subtypes (Figure 1b).

\section{Estrogen-mediated regulation of AGR2 gene expression}

Consistent with the correlation between AGR2 and ER expression in breast cancer cell lines [1] and ER-positive breast cancers $[3,13,25]$ and the expression of AGR2 in response to estrogen treatment in breast cancer cell lines [20], an in vivo study in which normal human mammary tissue was transplanted into female nude mice exhibited increased AGR2 expression in response to estradiol [32]. Collectively, these data provide strong evidence that AGR2 is regulated by estradiol under normal and pathophysiological conditions. Furthermore, these data suggest that AGR2 may be an important component of the profound estrogen response in breast tissue.

To determine whether ER directly regulates the AGR2 gene, Hrstka and colleagues [11] treated MCF-7 cells with estradiol and performed chromatin immunoprecipitation (ChIP) of ER-alpha, demonstrating a twofold increase in ER binding to the $A G R 2$ promoter upon estradiol treatment. Furthermore, ER-alpha was shown to increase expression from a transiently transfected AGR2 promoter reporter plasmid. These in vitro experiments suggest that ER binds directly to AGR2 to activate transcription of the gene.

Recent reports defining global ER-binding sites through ChIP-Seq and chromatin interaction analysis by pairedend tag sequencing (ChIA-Pet) further support the targeted binding and transcriptional activation of AGR2 by ER in cell lines and primary tumor tissue [23,33,34]. Treatment of MCF-7 cells with estradiol induces ER binding in the proximal promoter of $A G R 2$, subsequently activating $A G R 2$ transcription as evidenced by increased AGR2 gene expression and pervasive RNA polymerase II and histone $\mathrm{H} 3$ lysine 4 trimethylation (H3K4me3) marks on the chromatin [23] (Figure 2a). Interestingly, the same patterns of estradiol-induced ER binding and subsequent gene expression are observed for $A G R 3$, suggesting that AGR2 and AGR3 are both expressed in response to estrogen in MCF-7 cells. In addition, we used published peak calls from ChIP-Seq data collected from good- and poor-outcome ER-positive breast cancers, as well as metastases derived from ER-positive breast cancers [33], to search for ER binding in a 20-kb window around the AGR2 and AGR3 genes (Figure 2a). We found binding events surrounding $A G R 2$ in only one good-outcome tumor, whereas four of the seven poor-outcome tumors and all three metastases exhibited multiple ER-binding events around the $A G R 2$ gene. Similar binding patterns were observed near the $A G R 3$ gene. Five ER-positive cell lines were also profiled for ER binding, and all of them exhibited multiple ER-binding sites near AGR2 and AGR3 (Figure 2a). Furthermore, a separate study performing ChIP-Seq on MCF-7 cells reveals that both AGR2 and $A G R 3$ possess a single ER-binding event surrounding the gene in response to estradiol treatment [34], both of which overlap with binding events in the primary tumors and cell lines reported by Ross-Innes and colleagues [33]. Thus, estrogen-mediated activation of ER directly targets AGR2 and AGR3 for active gene transcription, and an increased number of occupied ER-binding sites may correlate with poor prognosis. Finally, studies using ChIA-Pet to identify long-range genome interactions found that ER mediates the formation of a 130-kb loop that includes both AGR2 and AGR3 [23] (Figure 2b), suggesting that transcriptional hubs generated by ERinduced looping of DNA control the transcription of both genes in MCF-7 cells treated with estradiol. Collectively, these studies give clear evidence that AGR2 is a direct target of ER in both cell lines and primary tumor cells from breast cancers.

In prostate cancer cells, both estrogens and androgens stimulate AGR2 expression [22,35], and in this case, the activation for both types of ligands seems to depend on the androgen receptor (AR), which binds the AGR2 gene [22]. The role of AR in regulating $A G R 2$ in breast cancer has not been investigated.

\section{AGR2 promotes resistance to tamoxifen treatment in ER-positive breast cancer}

Since AGR2 is a direct target of ER, one would expect ERpositive breast cancers treated with anti-estrogen therapy to exhibit decreased AGR2 levels. This is indeed the case in primary tumors treated with aromatase inhibitors, which reduce the systemic levels of estrogen by preventing the catalysis of androgens into estradiol, whereas the 
(a)

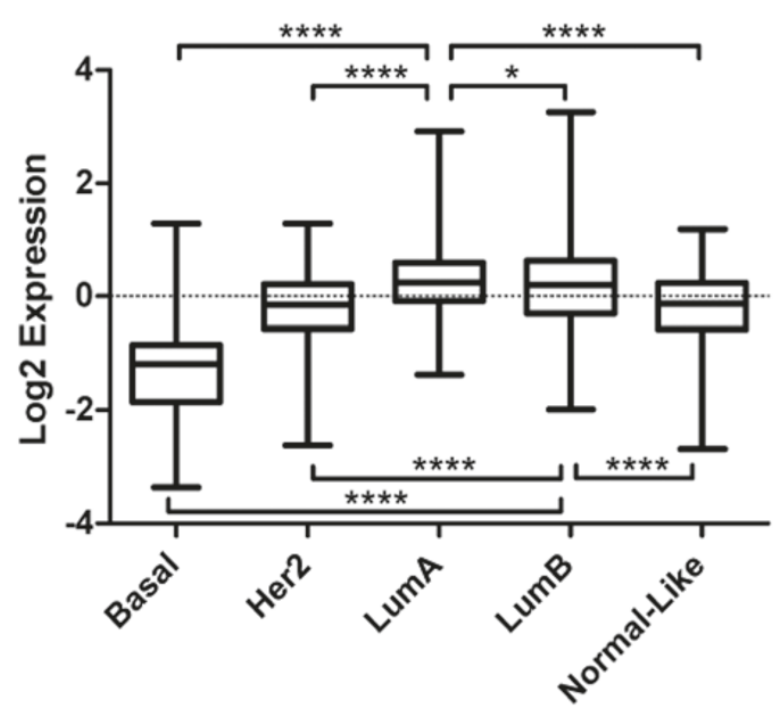

(b)

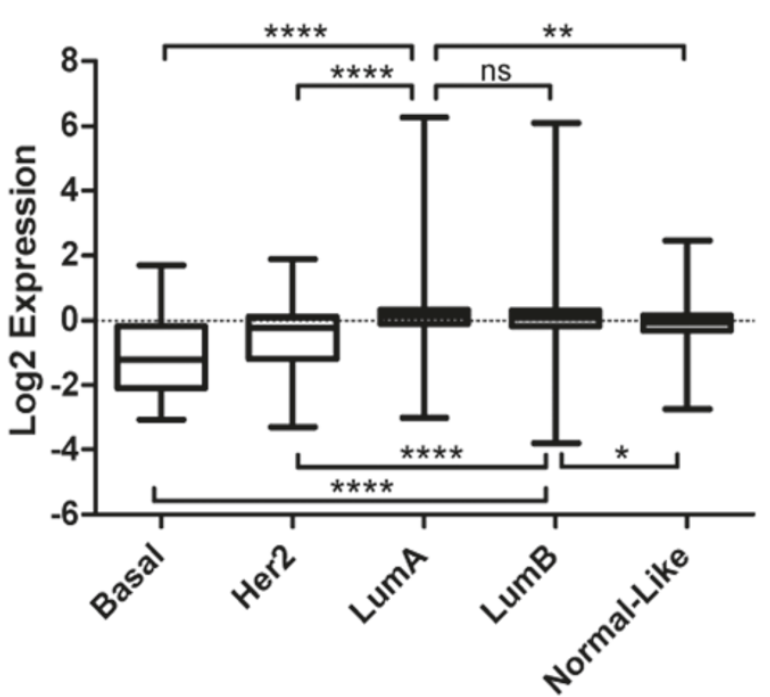

Figure 1. Overexpression of AGR2 and AGR3 in the ER-positive luminal A and B breast cancer subtypes. (a) Primary breast tumor gene expression data from three independent studies [29-31] with a total of 1,169 samples were log2-normalized and mean centered and then combined into one large data set. AGR2 is expressed significantly higher in the ER-positive luminal A (LumA) and B (LumB) subtypes and is lowly expressed in the ER-negative basal-like (Basal), Her2, and normal breast-like (Normal-Like) tumors. (b) AGR3 gene expression was analyzed in the same way as AGR2 and similarly was expressed significantly higher in LumA and LumB tumors. ${ }^{*} P<0.05$; ${ }^{* *} P<0.01$; ${ }^{* * * *} P<0.0001$. AGR2, anterior gradient 2; ER, estrogen receptor; ns, not significant.

opposite is observed when treating the tumor with tamoxifen, which blocks the binding of estradiol to its receptor [11,36]. Interestingly, in MCF-7 cells, tamoxifen treatment induces more robust ER binding to the AGR2 promoter, and subsequently a greater increase in AGR2 mRNA and protein, than estradiol treatment [11]. Similar results were provided by Hengel and colleagues [37], who searched for proteins induced by tamoxifen in a proteomics screen in MCF-7 cells and reported AGR2 to be the second most induced protein. In addition, ER-positive primary breast tumors treated with tamoxifen have increased AGR2 mRNA transcript levels [11]. In the breast, tamoxifen is classically described as an antagonist of estrogen-mediated signaling through ER, but these data suggest that tamoxifen, which has general agonist effects in the bone and uterus, also acts as an agonist for the AGR2 gene. Thus, the depletion of estradiol by aromatase inhibitors reduces AGR2 expression, presumably because of decreased overall activity of ER signaling, whereas the inhibition of estradiol binding to its receptor via tamoxifen enhances ER binding to the AGR2 promoter and subsequently increases gene expression.

Generally, the ER-positive subtype of breast cancer is less aggressive and is associated with good prognosis because of the relatively successful treatment with hormone therapies, such as tamoxifen. However, despite the effectiveness of tamoxifen in the clinical setting, approximately $50 \%$ of ER-positive tumors are intrinsically resistant to tamoxifen therapy and approximately $40 \%$ of ER-positive early-stage breast cancers that initially respond to endocrine therapy do eventually relapse with a disease resistant to tamoxifen $[38,39]$. The fact that AGR2 is selectively induced upon tamoxifen treatment could in part explain the intrinsic or acquired resistance (or both) of ER-positive breast cancers leading to decreased overall survival. This is supported by the finding that an increase in AGR2 levels in tamoxifenresistant ER-positive breast tumors is indicative of poor prognosis [11]. Thus, in the clinical setting, AGR2 may become a useful molecular marker for identifying ERpositive tumors that are unlikely to respond to tamoxifen and require new or additional treatments to circumvent this resistance, such as a combinatorial therapy that includes aromatase inhibitors. Recently, such combinatorial therapy has shown significant improvements in progression-free and overall survival of ER-positive metastatic breast cancers treated with a combination of the aromatase inhibitor anastrozole and the ER inhibitor fulvestrant [40]. As aromatase inhibitors reduce AGR2 expression and fulvestrant has been demonstrated to inhibit ER binding to the AGR2 promoter in MCF-7 cells, it is possible that AGR2 expression in these tumors has been reduced and contributed to the improved prognosis in these patients. 


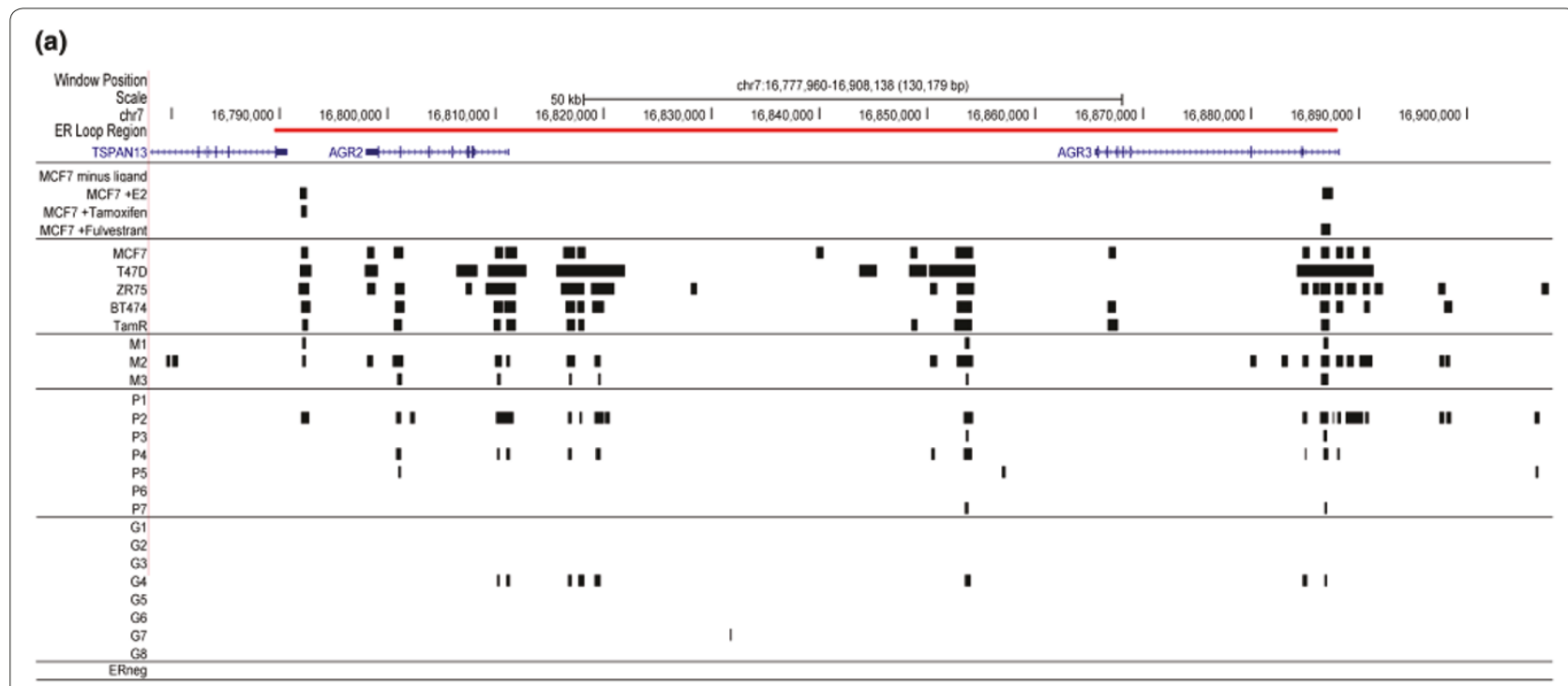

(b)
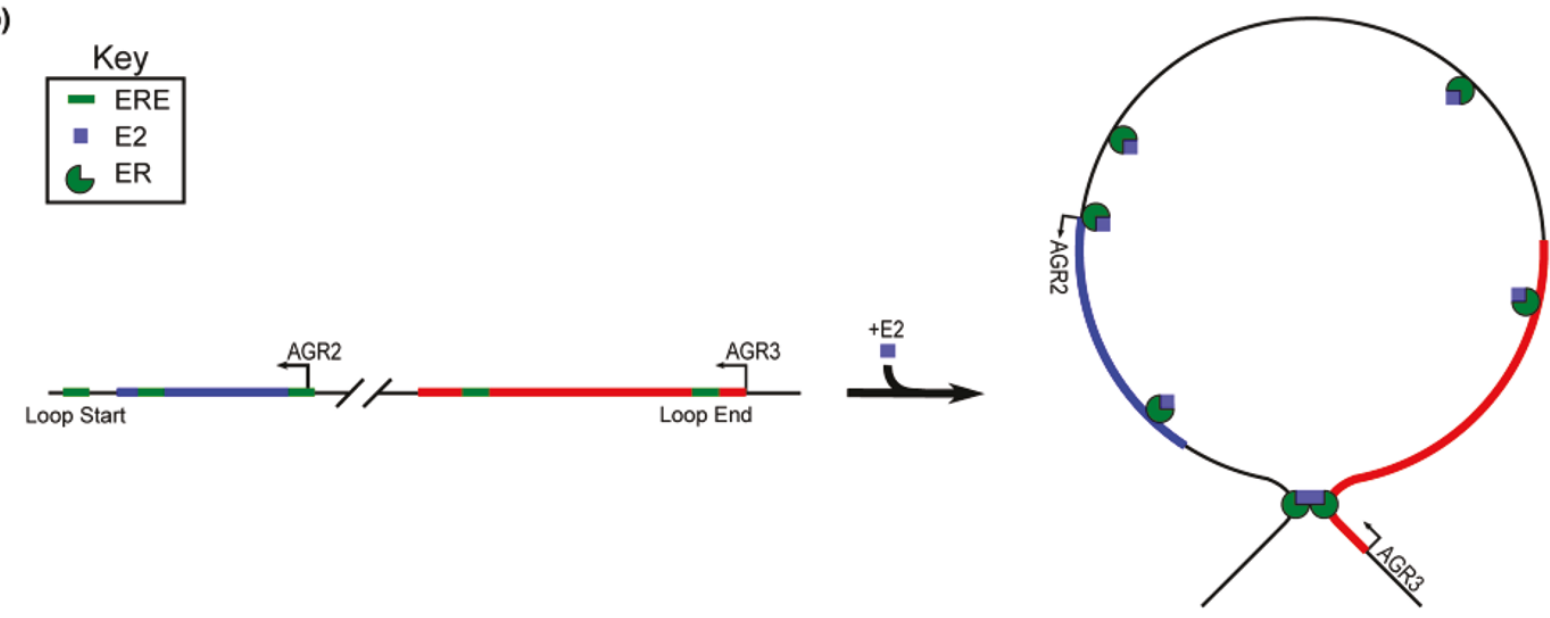

Figure 2. ER-binding and chromatin looping surrounding the $A G R 2$ and $A G R 3$ genes. (a) ER-binding sites surrounding the $A G R 2$ and $A G R 3$ are displayed for ER-positive cell lines and primary tumors. ChIA-Pet data in MCF-7 cells provided by Fullwood and colleagues [23] define an estradiolinduced loop mediated by ER-binding near AGR2 and AGR3 (ER-loop region indicated with red bar). Peaks defined by Welboren and colleagues [34] identify ER-binding upon treatment with estradiol in the proximal promoter of AGR2 and the first intron of AGR3 (MCF-7 minus ligand versus MCF-7 + E2). Treatment with tamoxifen alone (MCF-7 + Tamoxifen) induces ER binding to AGR2 but not AGR3, whereas treatment with fulvestrant alone (MCF-7 +Fulvestrant) induces ER binding to AGR3 but not AGR2. Ross-Innes and colleagues [33] profiled ER binding in tamoxifen-responsive (MCF-7, T47D, ZR75) and tamoxifen-resistant (BT474, TamR) cell lines and ER-positive primary breast tumors (M1-3, metastases; P1-7, poor-outcome tumors; G1-8, good-outcome tumors; ERneg, ER-negative tumor). Using the published peak data, we identified ER binding in only one good-prognosis tumor, whereas poor-prognosis and metastatic primary tumors display increased ER binding. Tamoxifen-resistant and -responsive cell lines display pervasive ER binding throughout the region. (b) ChIA-PET data from Fullwood and colleagues [23] identify an ER-mediated chromatin loop in MCF-7 cells spanning a 130-kb region that includes the AGR2 and AGR3 genes. The loop region, displayed as a red bar in (a), contains multiple putative ER-binding sites indicated by the location of the bound receptors in the loop. AGR2, anterior gradient 2; E2, estradiol; ER, estrogen receptor; ERE, estrogen response element.

The increased expression of AGR2 in ER-positive tumors that become resistant to tamoxifen treatment may be a result of (a) the selection and expansion of an intrinsically resistant subpopulation of cells that exhibit increased binding of ER to $A G R 2$ or (b) a unique tamoxifen-induced transcriptional program governed by ER that leads to increased binding to the $A G R 2$ gene or (c) both. In support of the former, differential binding of
ER has been described in a cohort of primary ER-positive breast tumors comparing good- and poor-outcome tumors prior to any treatment [33]. In this study, the authors identified a core set of 484 ER-binding sites common to both good- and poor-outcome tumors and 1,791 differentially bound sites (599 and 1,192 unique binding sites in good-outcome and poor-outcome tumors, respectively). Prognostic predictors built from 
the genes surrounding these sites are indicative of patient outcome in several independent studies in which gene expression and survival data are available, suggesting that the differential binding regions observed in these tumors could mediate the resistance to anti-cancer therapies, such as tamoxifen. As we noted earlier, these data suggest that $A G R 2$ is preferentially targeted by ER in the pooroutcome tumors and metastases. However, only four of the seven poor-outcome tumors exhibited binding sites near AGR2, indicating plasticity in ER binding even within poor-outcome tumors. As these samples were taken prior to any treatment, it is possible that the other three poor-prognosis tumors represent a population of tumors that become resistant in response to treatment rather than possessing intrinsic therapeutic resistance. To deconstruct the ER-binding patterns that promote intrinsic or induced therapeutic resistance, Ross-Innes and colleagues [33] profiled ER-binding patterns by ChIP-Seq in three tamoxifen-responsive cell lines (MCF-7, ZR75-1, and T-47D) and two tamoxifen-resistant cell lines (BT-474 and TAM-R, a resistant MCF-7 cell line); 6,920 ER-binding events were common to all five cell lines, whereas 8,188 were unique to the tamoxifen-resistant cells and 5,713 were unique to the responsive cells. The authors report that the unique binding events in the tamoxifen-responsive cell lines significantly overlap with those identified in the pooroutcome and metastatic tumors, suggesting that these cell lines more likely resemble poor-outcome tumors. We used the same data to identify ER-binding events surrounding AGR2 and found consistent binding across all five cell types, irrespective of sensitivity to tamoxifen (Figure 2a). In light of the conclusion that all five cell types resemble poor-outcome tumors, the elevated ER binding around $A G R 2$ in all of these cells further supports the association between ER-induced AGR2 expression in primary tumors and poor outcome. In conclusion, we believe that ER-mediated expression of AGR2 could be a hallmark of ER-positive breast carcinomas that can be exploited to identify tumors that will respond poorly to anti-hormone therapy and are poised for dissemination of metastatic tumor cells.

\section{AGR2 expression as an indicator of metastatic breast cancer}

Detection of metastatic cells in the lymph node or circulating tumor cells (CTCs) in the peripheral blood is strongly associated with poor clinical outcome in breast cancer [41-43]. AGR2 may be a fitting target for detection of metastatic cells as it has been found to promote metastasis in functional experiments and to be expressed in metastatic breast cancer cells in humans. AGR2induced lung metastases were identified in a rat model overexpressing AGR2 in benign breast tumors, apparently through both blood-borne and lymphatic routes, giving strong in vivo evidence that the overexpression of AGR2 alone is sufficient to induce metastases [13]. Consistent with these animal experiments, AGR2 mRNA has been observed in metastatic epithelial cells isolated from the sentinel lymph nodes of patients with breast cancer [41]. In addition, AGR2 gene expression in blood samples of patients with breast, colorectal, prostate, urothelial, or gastrointestinal cancer is capable of identifying CTCs [42-45]. Thus, the expression of AGR2 in the blood samples of patients with breast cancer or other adenocarcinoma may be a useful indicator of metastatic cancer that will require a more aggressive treatment regimen.

\section{AGR2 mechanisms of action in breast cancer}

Despite the thorough characterization of AGR2 expression in normal development and breast cancer and other adenocarcinomas, the function of AGR2 in these tissues remains poorly understood. However, given the functional domains characterized in the AGR2 protein and its localization to both the endoplasmic reticulum and the extracellular membrane, it is likely that AGR2 has a role in relieving endoplasmic reticulum stress, promoting the dissemination of metastatic tumor cells, and stimulating cell survival and proliferation (Figure 3).

\section{AGR2 as a reliever of endoplasmic reticulum stress in breast cancer}

Cancer cells must adapt to survive proteotoxic stress created from imbalances in transcriptional output that result in high volumes of translation [46]. High protein translation rates lead to the sequestration of unfolded protein in the endoplasmic reticulum, exerting a burden on the protein-folding and degradation machinery that ultimately creates a toxic cellular environment [47]. This imbalance is counteracted by recruiting protein-folding or proteolytic degradation factors (or both) to relieve this stress, and one example is the chaperone HSP90 that participates in protein folding; HSP90 is expressed in tumor cells in response to excess unfolded protein [48]. Notably, the HSP90 co-chaperone p23 has been reported to induce expression of AGR2 and promote tumor progression, metastases, and drug resistance in breast cancer [49]. Thus, AGR2 may be recruited to the endoplasmic reticulum to assist in the protein-folding machinery to alleviate proteotoxic stress.

As a member of the PDI family, AGR2 aids protein folding and assembly by catalyzing the formation, reduction, and isomerization of disulfide bonds, thereby stabilizing intermediate conformations during protein maturation in the endoplasmic reticulum [15,50]. Its expression, which can be controlled by the unfolded protein response, is involved in the maintenance of 


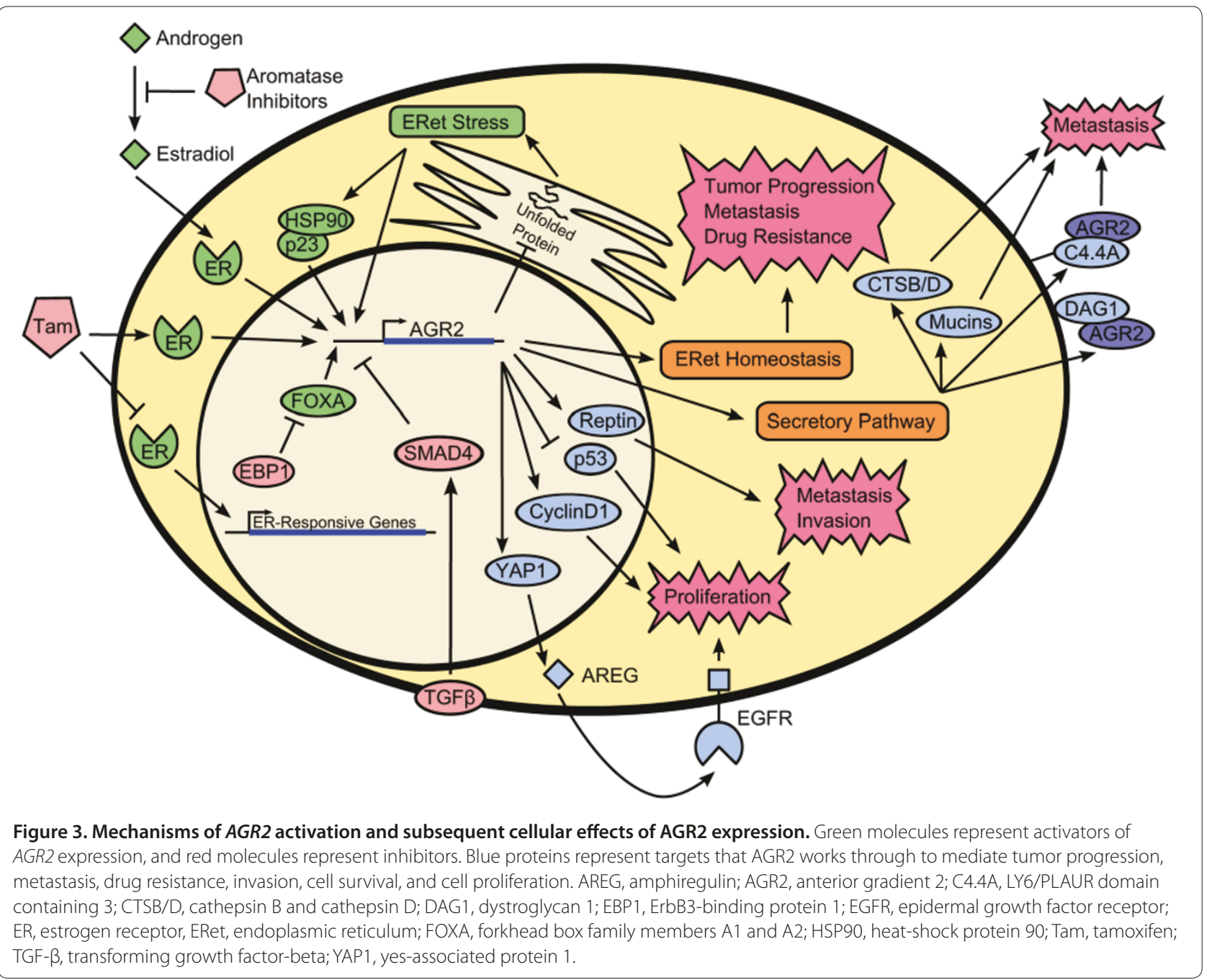

endoplasmic reticulum homeostasis by acting as a checkpoint in the endoplasmic reticulum quality control system and by redirecting misfolded proteins to the ERAD machinery $[14,15]$. AGR2 contains a putative endoplasmic reticulum retention motif and has been demonstrated to indirectly associate with endoplasmic reticulum membrane-bound ribosomes via nascent protein chains, presumably acting through a CXXS thioredoxin-like domain motif that may assist in disulfide bond formation and isomerization. Although thioredoxin activity of AGR2 has yet to be demonstrated, it has been shown to enhance endoplasmic reticulum folding capacity in cancer cells, allowing them to cope with acute endoplasmic reticulum stress [15]. It has also been shown to be important for the homeostasis of intestinal cells by relieving endoplasmic reticulum stress [51]. AGR2 likely plays a similar role in normal mammary development as it is most highly expressed during late pregnancy and lactation [20], a period during which high volumes of milk protein are produced in the secretory alveolar buds that may benefit from the assistance of additional protein-folding and secretory factors such as AGR2 to cope with the increased protein load. In addition, milk protein expression at the mRNA level is downregulated in a mammary-specific Agr2 knockout mouse model and upregulated in a mammary-specific Agr 2 overexpression mouse model [20], suggesting that AGR2 may play a role as a gatekeeper at both the protein and mRNA level to regulate the total protein load a cell can withstand without entering proteotoxic-induced cell death pathways. Tumor cells may overexpress AGR2 to promote cell survival by allowing the cell to withstand excess protein production associated with transformed cells. Major histocompatibility complex-1 (MHC-1) molecules, important for tumor surveillance, are potential targets of AGR2 as other PDIs have been shown to play a role in their folding and antigen loading [52,53]. In this respect, it is of interest that AGR2 has been used 
as an immunotherapy target in experimental colorectal cancer [54].

A proposed method of general cancer treatment is to induce proteotoxic stress through the inhibition of protein-folding and protein degradation machinery. Targeted inhibition of AGR2, or any other protein involved in either the protein-folding or degradation pathways, would sensitize the tumor cell to proteotoxic stress and suppress tumorigenesis. The anti-cancer drug geldanamycin induces proteotoxic stress by inhibiting HSP90 through its required ATPase domain and could possibly inhibit the expression of AGR2 as it has been shown to be a downstream target of the HSP90 cochaperone p23 [49]. Thus, the use of geldanamycin or the development of other proteotoxic stress-inducing anticancer drugs may be useful in a combinatorial therapy with anti-estrogens to treat ER-positive tumors that overexpress AGR2.

\section{Mechanistic roles of AGR2 in promoting breast cancer metastasis}

The AGR2 protein contains a canonical cleavable Nterminal signal peptide targeting it to the secretory pathway and has been biochemically demonstrated to be localized to secretory endosome-like organelles and at the extracellular surface $[18,55]$. Several secreted proteins, including the metastasis-associated GPI-anchored C4.4A protein and the extracellular domain of alpha-dystroglycan (DAG-1) [3,51,56], have been found in in vitro experiments to directly interact with AGR2, suggesting potential mechanisms for AGR2 in promoting tumor metastasis [13] through the regulation of receptor adhesion and interaction with extracellular matrix. Although these functions have not been validated at the molecular level, they are supported by work on other cancers in which AGR2, acting as a cell surface antigen, is involved in the dissemination of pancreatic tumor cells through the activation of cathepsins B and D [55]. Together, these data suggest that, in addition to being active within the endoplasmic reticulum, AGR2 is a secreted protein that interacts with the cell surface to modulate adhesion and promote dissemination of tumor cells.

AGR2 may also promote the production of mucins (MUCs), a family of secreted and transmembrane proteins that provide a protective mucous barrier to epithelial cells and, when overexpressed in breast cancer, participate in cell signaling to promote proliferation, invasion, and metastasis [57,58]. MUC1, overexpressed in most breast cancers, is an ER-responsive gene [59] that also interacts with ER to stabilize the protein and enhance binding to DNA [60]. AGR2 has been demonstrated to be an essential regulator of intestinal MUC2 [51,56], the airway epithelial MUC5AC and MUC5B [61], and pancreatic MUC1 production important for tumor initiation and progression [14]. Although studies on the role of AGR2 in promoting MUC expression are lacking, it is plausible that AGR2 could promote breast cancer metastasis through the regulation of MUCs.

Further evidence that AGR2 promotes the dissemination of tumor cells lies within the nucleus. At the transcriptional level, ErbB3-binding protein 1 (EBP1) suppresses the invasive ability of prostate cancer cells by inhibiting FOXA1- and FOXA2-mediated expression of AGR2 and thereby decreasing the metastatic behavior of these cells [62]. At the protein level, AGR2 binds in the nucleus to Reptin [63], which has been reported to modulate the invasive activity of cancer cells with metastatic potential [64]. As a member of the highly conserved RuvBl1/2 superfamily, Reptin contains two ATP-binding motifs, and loss or gain of ATP binding at these sites results in altered AGR2-binding properties. AGR2 uses a divergent peptide substrate-binding loop to bind to Reptin, and this interaction site could be a target for inhibiting the AGR2-Reptin complex, which would be highly relevant as Reptin can form protein-protein interactions with many proteins implicated in cancer, including Myc, Tip60, APPL1, Pontin, and telomerase holoenzyme complexes [65-68]. Therefore, the validation of Reptin as an AGR2-binding protein gives rise to a potentially novel signaling complex involved in prometastatic cancer development [63].

\section{AGR2 as a regulator of cell proliferation}

Several pieces of evidence suggest that AGR2 is a regulator of cell proliferation, although the molecular mechanisms by which it acts on cell proliferation are poorly understood. In the context of normal mammary gland morphogenesis, deletion of AGR2 in the mouse mammary gland leads to reduced lobuloalveolar development during late stages of pregnancy, whereas forced AGR2 expression leads to precocious lobuloalveolar development [20]. Functionally, AGR2 was demonstrated to regulate cell proliferation in these models, as the Agr2null and Agr2-overexpressing mice exhibited reduced and increased cell proliferation, respectively. In addition, transient AGR2 knockdown in MCF-7 cells significantly reduced the number of estradiol-induced proliferating cells, implicating AGR2 as an estrogen-responsive regulator of proliferation in breast cancer cells. Understanding the connection between ER-mediated AGR2 expression and normal cell proliferation could give novel insights into the effects of AGR2 overexpression and subsequent cell proliferation in ER-positive breast cancer.

Recent work suggests that AGR2 is incorporated in several pathways that promote tumor cell growth and survival. In lung and esophageal adenocarcinoma cell lines, AGR2 induces the expression of the epidermal 
growth factor receptor (EGFR) ligand amphiregulin (AREG) via the Hippo signaling pathway co-activator YAP1 and subsequently stimulates EGFR signaling and proliferation [69]. In addition, AGR2 promotes cell cycle progression and cell survival in ER-positive breast cancer cell lines via multiple cancer signaling pathways, mainly $\mathrm{ER}$, cyclin D1, pSrc, c-Myc, and survivin [12]. Furthermore, Aryl hydrocarbon receptor (AhR) signaling activated by genotoxicants induces the expression of AGR2, ultimately leading to tumor progression by inhibiting DNA-damage response through p53 activity [70]. In Barrett's esophagus, AGR2 is overexpressed and was demonstrated to repress p53 activity by inhibiting phosphorylation of the protein in response to DNA damage, thereby promoting cell survival [71]. As such, therapeutically targeting the AGR2 pathway may prove to be beneficial to attenuate cell proliferation and induce p53-dependent apoptosis.

Further evidence that AGR2 participates in cell proliferation is provided by its targeted regulation by transforming growth factor-beta (TGF- $\beta$ ) signaling, which governs multiple aspects of cell behavior, including proliferation, apoptosis, differentiation, and migration. In normal epithelial cells and early-stage breast carcinogenesis, TGF- $\beta$ acts as an inhibitor to cell proliferation; however, in advanced-stage tumors, it promotes cell survival, motility, and invasiveness [72]. In pancreatic ductal adenocarcinoma, AGR2 gene expression is suppressed by TGF- $\beta$ in a SMAD4-dependent manner [14]. Mutations to SMAD4 lead to the overexpression of AGR2 and consequently tumor progression. Thus, AGR2 could be a contributor to the TGF- $\beta$ switch from cytostatic effects to promotion of malignancy. Collectively, these data provide strong evidence for AGR2 regulation of cell proliferation in cancer through multiple signaling pathways.

\section{Conclusions}

AGR2 plays an important role in the development and progression of breast cancer and several other adenocarcinomas. Its expression, stimulated by ER signaling and endoplasmic reticulum stress, correlates with poor outcome in patients with breast cancer. It acts by promoting tumor metastasis, cell survival, cell proliferation, and resistance to anti-hormone therapies. Mechanistically, AGR2 assists in protein folding to maintain endoplasmic reticulum homeostasis, interacts with the extracellular matrix through its location on the cell surface, and is thought to promote cell proliferation through several signaling pathways. Further investigation into these mechanistic functions is necessary to elucidate the cellular networks through which AGR2 regulates tumor progression and metastasis. The recent generation of AGR2 inducible knockout and overexpression mouse models provides opportunities to study the mechanisms of AGR2 in breast cancer and other adenocarcinomas [20]. Many questions regarding the functional role of AGR2 in normal mammary gland development and breast cancer remain, such as whether AGR2 is a key mediator of ER-mediated cell proliferation. The mechanism for heterogeneous AGR2 expression in ER-positive breast cancer, in addition to how tamoxifen acts as an agonist to AGR2 expression, needs to be explored. Furthermore, there is a need to determine how important PDI function is for the biological effects of AGR2 in the mammary gland and breast cancer, and if AGR2 functions primarily as a PDI, its key enzymatic targets need to be defined. If AGR2 is a key survival factor, allowing ER-positive breast cancer cells to overcome endoplasmic reticulum stress, it may become an effective therapeutic target in breast cancer. Further studies into the development of drugs targeting AGR2 and the pathways that it mediates may lead to useful treatment options for patients with difficult-to-treat tamoxifenresistant and metastatic tumors. A therapy directly targeting AGR2 would also prove beneficial to the treatment of the many other adenocarcinomas that are dependent on the function of AGR2. However, it would be necessary to determine the relevance of AGR3 in these tumors, as it may be able to compensate for the loss of AGR2. Future drugs may have to target both AGR2 and AGR3 to be effective. In addition to being a treatment target, AGR2 is a marker of poor prognosis and can be used to identify CTCs and breast cancer metastasis.

\section{Abbreviations}

AGR2, anterior gradient 2; ChIP, chromatin immunoprecipitation; CTC, circulating tumor cell; EGFR, epidermal growth factor receptor; ER, estrogen receptor; ERP, endoplasmic reticulum protein; MUC, mucin; PDI, protein disulfide isomerase; TGF- $\beta$, transforming growth factor-beta.

\section{Competing interests}

The authors declare that they have no competing interests.

\section{Acknowledgments}

This work was supported by grants from the National Institutes of Health $(\mathrm{NIH})$ and the Irving Weinstein Foundation (to BA) and by the NIH Biomedical Informatics Training Grant T15LM0744 from the National Library of Medicine (to MLS).

\section{Author details}

'Departments of Medicine and Biological Chemistry, University of California, Sprague Hall, Room 206, Irvine, CA 92697-4030, USA. 'Departments of Medicine and Genetic Medicine, Weill Cornell Medical College, 541 East 71st Street, New York, NY 10021, USA.

\section{Published: 24 April 2013}

\section{References}

1. Kuang WW, Thompson DA, Hoch RV, Weigel RJ: Differential screening and suppression subtractive hybridization identified genes differentially expressed in an estrogen receptor-positive breast carcinoma cell line. Nucleic Acids Res 1998, 26:1116-1123.

2. Thompson DA, Weigel RJ: hAG-2, the human homologue of the Xenopus laevis cement gland gene XAG-2, is coexpressed with estrogen receptor in breast cancer cell lines. Biochem Biophys Res Commun 1998, 251:111-116. 
3. Fletcher GC, Patel S, Tyson K, Adam PJ, Schenker M, Loader JA, Daviet L, Legrain P, Parekh R, Harris AL, Terrett JA: hAG-2 and hAG-3, human homologues of genes involved in differentiation, are associated with oestrogen receptor-positive breast tumours and interact with metastasis gene C4.4a and dystroglycan. Br J Cancer 2003, 88:579-585.

4. Maresh EL, Mah V, Alavi M, Horvath S, Bagryanova L, Liebeskind ES, Knutzen LA, Zhou Y, Chia D, Liu AY, Goodglick L: Differential expression of anterior gradient gene AGR2 in prostate cancer. BMC Cancer 2010, 10:680.

5. Park K, Chung YJ, So H, Kim K, Park J, Oh M, Jo M, Choi K, Lee EJ, Choi YL, Song SY, Bae DS, Kim BG, Lee JH: AGR2, a mucinous ovarian cancer marker, promotes cell proliferation and migration. Exp Mol Med 2011, 43:91-100.

6. Pizzi M, Fassan M, Balistreri M, Galligioni A, Rea F, Rugge M: Anterior gradient 2 overexpression in lung adenocarcinoma. Appl Immunohistochem Mol Morphol 2012, 20:31-36.

7. Ramachandran V, Arumugam T, Wang H, Logsdon CD: Anterior gradient 2 is expressed and secreted during the development of pancreatic cancer and promotes cancer cell survival. Cancer Res 2008, 68:7811-7818.

8. Wang Z, Hao Y, Lowe AW: The adenocarcinoma-associated antigen, AGR2, promotes tumor growth, cell migration, and cellular transformation. Cancer Res 2008, 68:492-497.

9. Fritzsche FR, Dahl E, Pahl S, Burkhardt M, Luo J, Mayordomo E, Gansukh T, Dankof A, Knuechel R, Denkert C, Winzer KJ, Dietel M, Kristiansen G: Prognostic relevance of AGR2 expression in breast cancer. Clin Cancer Res 2006, 12:1728-1734.

10. Kim HS, Kang SH, Park CH, Yang Wl, Jeung HC, Chung HC, Roh JK, Ahn JB, Kim NK, Min BS, Rha SY: Genome-wide molecular characterization of mucinous colorectal adenocarcinoma using cDNA microarray analysis. Oncol Rep 2011, 25:717-727.

11. Hrstka R, Nenutil R, Fourtouna A, Maslon MM, Naughton C, Langdon S, Murray E, Larionov A, Petrakova K, Muller P, Dixon MJ, Hupp TR, Vojtesek B: The pro-metastatic protein anterior gradient-2 predicts poor prognosis in tamoxifen-treated breast cancers. Oncogene 2010, 29:4838-4847.

12. Vanderlaag KE, Hudak S, Bald L, Fayadat-Dilman L, Sathe M, Grein J, Janatpour MJ: Anterior gradient-2 plays a critical role in breast cancer cell growth and survival by modulating cyclin D1, estrogen receptor-alpha and survivin. Breast Cancer Res 2010, 12:R32.

13. Liu D, Rudland PS, Sibson DR, Platt-Higgins A, Barraclough R: Human homologue of cement gland protein, a novel metastasis inducer associated with breast carcinomas. Cancer Res 2005, 65:3796-3805.

14. Norris AM, Gore A, Balboni A, Young A, Longnecker DS, Korc M: AGR2 is a SMAD4-suppressible gene that modulates MUC1 levels and promotes the initiation and progression of pancreatic intraepithelial neoplasia. Oncogene 2012, Sep 3 [Epub ahead of print].

15. Higa A, Mulot A, Delom F, Bouchecareilh M, Nguyên DT, Boismenu D, Wise MJ, Chevet $\mathrm{E}$ : Role of pro-oncogenic protein disulfide isomerase (PDI) family member anterior gradient 2 (AGR2) in the control of endoplasmic reticulum homeostasis. J Biol Chem 2011, 286:44855-44868.

16. Benham AM: The protein disulfide isomerase family: key players in health and disease. Antioxid Redox Signal 2012, 16:781-789.

17. Aberger $F$, Weidinger $G$, Grunz H, Richter K: Anterior specification of embryonic ectoderm: the role of the Xenopus cement gland-specific gene XAG-2. Mech Dev 1998, 72:115-130.

18. Adam PJ, Boyd R, Tyson KL, Fletcher GC, Stamps A, Hudson L, Poyser HR, Redpath N, Griffiths M, Steers G, Harris AL, Patel S, Berry J, Loader JA, Townsend RR, Daviet L, Legrain P, Parekh R, Terrett JA: Comprehensive proteomic analysis of breast cancer cell membranes reveals unique proteins with potential roles in clinical cancer. J Biol Chem 2003, 278:6482-6489.

19. Petek E, Windpassinger $C$, Egger $H$, Kroisel PM, Wagner K: Localization of the human anterior gradient-2 gene (AGR2) to chromosome band 7p21.3 by radiation hybrid mapping and fluorescencein situ hybridisation. Cytogenet Cell Genet 2000, 89:141-142.

20. Verma S, Salmans ML, Geyfman M, Wang H, Yu Z, Lu Z, Zhao F, Lipkin SM, Andersen $B$ : The estrogen-responsive Agr 2 gene regulates mammary epithelial proliferation and facilitates lobuloalveolar development. Dev Biol 2012, 369:249-260

21. Gray TA, MacLaine NJ, Michie CO, Bouchalova P, Murray E, Howie J, Hrstka R, Maslon MM, Nenutil R, Vojtesek B, Langdon S, Hayward L, Gourley C, Hupp TR: Anterior Gradient-3: a novel biomarker for ovarian cancer that mediates cisplatin resistance in xenograft models. J Immunol Methods 2012, 378:20-32.
22. Bu H, Schweiger MR, Manke T, Wunderlich A, Timmermann B, Kerick M, Pasqualini L, Shehu E, Fuchsberger C, Cato AC, Klocker H: Anterior gradient 2 and 3 - two prototype androgen-responsive genes transcriptionally upregulated by androgens and by oestrogens in prostate cancer cells. FEBS J 2013, 280:1249-1266

23. Fullwood MJ, Liu MH, Pan YF, Liu J, Xu H, Mohamed YB, Orlov YL, Velkov S, Ho A, Mei PH, Chew EG, Huang PY, Welboren WJ, Han Y, Ooi HS, Ariyaratne PN, Vega VB, Luo Y, Tan PY, Choy PY, Wansa KD, Zhao B, Lim KS, Leow SC, Yow JS, Joseph R, Li H, Desai KV, Thomsen JS, Lee YK, Karuturi RK, Herve T, Bourque G, Stunnenberg HG, Ruan X, Cacheux-Rataboul V, Sung WK, Liu ET, Wei CL, Cheung E, Ruan Y: An oestrogen-receptor-alpha-bound human chromatin interactome. Nature 2009, 462:58-64.

24. Persson S, Rosenquist M, Knoblach B, Khosravi-Far R, Sommarin M, Michalak M: Diversity of the protein disulfide isomerase family: identification of breast tumor induced Hag2 and Hag3 as novel members of the protein family. Mol Phylogenet Evol 2005, 36:734-740.

25. Innes HE, Liu D, Barraclough R, Davies MP, O'Neill PA, Platt-Higgins A, de Silva Rudland S, Sibson DR, Rudland PS: Significance of the metastasis-inducing protein AGR2 for outcome in hormonally treated breast cancer patients. Br J Cancer 2006, 94:1057-1065.

26. Barraclough DL, Platt-Higgins A, de Silva Rudland S, Barraclough R, Winstanley $J$, West CR, Rudland PS: The metastasis-associated anterior gradient 2 protein is correlated with poor survival of breast cancer patients. Am J Pathol 2009, 175:1848-1857.

27. Zweitzig DR, Smirnov DA, Connelly MC, Terstappen LW, O'Hara SM, Moran E: Physiological stress induces the metastasis marker AGR2 in breast cancer cells. Mol Cell Biochem 2007, 306:255-260.

28. Perou CM, Sørlie T, Eisen MB, van de Rijn M, Jeffrey SS, Rees CA, Pollack JR, Ross DT, Johnsen H, Akslen LA, Fluge O, Pergamenschikov A, Williams C, Zhu SX, Lønning PE, Børresen-Dale AL, Brown PO, Botstein D: Molecular portraits of human breast tumours. Nature 2000, 406:747-752.

29. van de Vijver MJ, He YD, van't Veer LJ, Dai H, Hart AA, Voskuil DW, Schreiber GJ, Peterse JL, Roberts C, Marton MJ, Parrish M, Atsma D, Witteveen A, Glas A, Delahaye L, van der Velde T, Bartelink H, Rodenhuis S, Rutgers ET, Friend SH, Bernards R: A gene-expression signature as a predictor of survival in breast cancer. NEngl J Med 2002, 347:1999-2009.

30. Prat A, Parker JS, Karginova O, Fan C, Livasy C, Herschkowitz II, He X, Perou CM: Phenotypic and molecular characterization of the claudin-low intrinsic subtype of breast cancer. Breast Cancer Res 2010, 12:R68.

31. Guedj M, Marisa L, de Reynies A, Orsetti B, Schiappa R, Bibeau F, MacGrogan $G$, Lerebours F, Finetti P, Longy M, Bertheau P, Bertrand F, Bonnet F, Martin AL, Feugeas JP, Bièche I, Lehmann-Che J, Lidereau R, Birnbaum D, Bertucci F, de Thé $H$, Theillet $C:$ A refined molecular taxonomy of breast cancer. Oncogene 2011, 31:1196-1206.

32. Wilson CL, Sims AH, Howell A, Miller CJ, Clarke RB: Effects of oestrogen on gene expression in epithelium and stroma of normal human breast tissue. Endocr Relat Cancer 2006, 13:617-628.

33. Ross-Innes CS, Stark R, Teschendorff AE, Holmes KA, Ali HR, Dunning MJ, Brown GD, Gojis O, Ellis IO, Green AR, Ali S, Chin SF, Palmieri C, Caldas C, Carroll JS: Differential oestrogen receptor binding is associated with clinical outcome in breast cancer. Nature 2012, 481:389-393.

34. Welboren W-J, Driel MAv, Janssen-Megens EM, Heeringen SJv, Sweep FC, Span PN, Stunnenberg HG: ChIP-Seq of ER|[alpha]| and RNA polymerase II defines genes differentially responding to ligands. EMBO J 2009, 28:1418-1428.

35. Zhang JS, Gong A, Cheville JC, Smith DI, Young CY: AGR2, an androgeninducible secretory protein overexpressed in prostate cancer. Genes Chromosomes Cancer 2005, 43:249-259.

36. Mackay A, Urruticoechea A, Dixon JM, Dexter T, Fenwick K, Ashworth A, Drury S, Larionov A, Young O, White S, Miller WR, Evans DB, Dowsett M: Molecular response to aromatase inhibitor treatment in primary breast cancer. Breast Cancer Res 2007, 9:R37.

37. Hengel SM, Murray E, Langdon S, Hayward L, O'Donoghue J, Panchaud A, Hupp T, Goodlett DR: Data-independent proteomic screen identifies novel tamoxifen agonist that mediates drug resistance. J Proteome Res 2011, 10:4567-4578.

38. Coser KR, Wittner BS, Rosenthal NF, Collins SC, Melas A, Smith SL, Mahoney CJ, Shioda K, Isselbacher KJ, Ramaswamy S, Shioda T: Antiestrogen-resistant subclones of MCF-7 human breast cancer cells are derived from a common monoclonal drug-resistant progenitor. Proc Natl Acad Sci U S A 2009, 106:14536-14541. 
39. Clarke R, Liu MC, Bouker KB, Gu Z, Lee RY, Zhu Y, Skaar TC, Gomez B, O'Brien K, Wang Y, Hilakivi-Clarke LA: Antiestrogen resistance in breast cancer and the role of estrogen receptor signaling. Oncogene 2003, 22:7316-7339.

40. Mehta RS, Barlow WE, Albain KS, Vandenberg TA, Dakhil SR, Tirumali NR, Lew DL, Hayes DF, Gralow JR, Livingston RB, Hortobagyi GN: Combination anastrozole and fulvestrant in metastatic breast cancer. N Engl J Med 2012, 367:435-444.

41. Tveito S, Andersen K, Kåresen R, Fodstad Ø: Analysis of EpCAM positive cells isolated from sentinel lymph nodes of breast cancer patients identifies subpopulations of cells with distinct transcription profiles. Breast Cancer Res 2011, 13:R75.

42. Smirnov DA, Zweitzig DR, Foulk BW, Miller MC, Doyle GV, Pienta KJ, Meropol NJ, Weiner LM, Cohen SJ, Moreno JG, Connelly MC, Terstappen LW, O'Hara SM: Global gene expression profiling of circulating tumor cells. Cancer Res 2005, 65:4993-4997.

43. da Costa A, Lenze D, Hummel M, Kohn B, Gruber AD, Klopfleisch R: Identification of six potential markers for the detection of circulating canine mammary tumour cells in the peripheral blood identified by microarray analysis. J Comp Pathol 2012, 146:143-151.

44. Marín-Aguilera M, Mengual L, Ribal MJ, Ars E, Ríos J, Gázquez C, Villavicencio $\mathrm{H}$, Alcaraz A: Utility of urothelial mRNA markers in blood for staging and monitoring bladder cancer. Urology 2012, 79:240.e249-215.

45. Valladares-Ayerbes M, Díaz-Prado S, Reboredo M, Medina V, Iglesias-Díaz P, Lorenzo-Patiño MJ, Campelo RG, Haz M, Santamarina I, Antón-Aparicio LM: Bioinformatics approach to mRNA markers discovery for detection of circulating tumor cells in patients with gastrointestinal cancer. Cancer Detect Prev 2008, 32:236-250

46. Luo J, Solimini NL, Elledge SJ: Principles of cancer therapy: oncogene and non-oncogene addiction. Cell 2009, 136:823-837.

47. Denoyelle C, Abou-Rjaily G, Bezrookove V, Verhaegen M, Johnson TM, Fullen DR, Pointer JN, Gruber SB, Su LD, Nikiforov MA, Kaufman RJ, Bastian BC, Soengas MS: Anti-oncogenic role of the endoplasmic reticulum differentially activated by mutations in the MAPK pathway. Nat Cell Biol 2006, 8:1053-1063.

48. Whitesell L, Lindquist SL: HSP90 and the chaperoning of cancer. Nat Rev Cancer 2005, 5:761-772.

49. Simpson NE, Lambert WM, Watkins R, Giashuddin S, Huang SJ, Oxelmark E, Arju R, Hochman T, Goldberg JD, Schneider RJ, Reiz LF, Soares FA, Logan SK, Garabedian MJ: High levels of Hsp90 cochaperone p23 promote tumor progression and poor prognosis in breast cancer by increasing lymph node metastases and drug resistance. Cancer Res 2010, 70:8446-8456.

50. Sevier CS, Kaiser CA: Formation and transfer of disulphide bonds in living cells. Nat Rev Mol Cell Biol 2002, 3:836-847.

51. Zhao F, Edwards R, Dizon D, Afrasiabi K, Mastroianni JR, Geyfman M, Ouellette AJ, Andersen B, Lipkin SM: Disruption of Paneth and goblet cell homeostasis and increased endoplasmic reticulum stress in Agr2-/- mice. Dev Biol 2010, 338:270-279.

52. Kang K, Park B, Oh C, Cho K, Ahn K: A role for protein disulfide isomerase in the early folding and assembly of MHC class I molecules. Antioxid Redox Signal 2009, 11:2553-2561.

53. Cho K, Cho S, Lee SO, Oh C, Kang K, Ryoo J, Lee S, Kang S, Ahn K: Redoxregulated peptide transfer from the transporter associated with antigen processing to major histocompatibility complex class I molecules by protein disulfide isomerase. Antioxid Redox Signal 2011, 15:621-633.

54. Lee HJ, Hong CY, Kim MH, Lee YK, Nguyen-Pham TN, Park BC, Yang DH, Chung IJ, Kim HJ, Lee JJ: In vitro induction of anterior gradient-2-specific cytotoxic T lymphocytes by dendritic cells transduced with recombinant adenoviruses as a potential therapy for colorectal cancer. Exp Mol Med 2012, 44:60-67.

55. Dumartin L, Whiteman HJ, Weeks ME, Hariharan D, Dmitrovic B, lacobuzioDonahue CA, Brentnall TA, Bronner MP, Feakins RM, Timms JF, Brennan C, Lemoine NR, Crnogorac-Jurcevic T: AGR2 is a novel surface antigen that promotes the dissemination of pancreatic cancer cells through regulation of cathepsins B and D. Cancer Res 2011, 71:7091-7102.

56. Park SW, Zhen G, Verhaeghe C, Nakagami Y, Nguyenvu LT, Barczak AJ, Killeen $\mathrm{N}$, Erle DJ: The protein disulfide isomerase AGR2 is essential for production of intestinal mucus. Proc Natl Acad Sci U S A 2009, 106:6950-6955.

57. Kufe DW: Mucins in cancer: function, prognosis and therapy. Nat Rev Cancer 2009, 9:874-885.

58. Mukhopadhyay P, Chakraborty S, Ponnusamy MP, Lakshmanan I, Jain M, Batra SK: Mucins in the pathogenesis of breast cancer: implications in diagnosis, prognosis and therapy. Biochim Biophys Acta 2011, 1815:224-240.

59. Wang J, Jarrett J, Huang CC, Satcher RL, Levenson AS: Identification of estrogen-responsive genes involved in breast cancer metastases to the bone. Clin Exp Metastasis 2007, 24:411-422.

60. Wei X, Xu H, Kufe D: MUC1 oncoprotein stabilizes and activates estrogen receptor alpha. Mol Cell 2006, 21:295-305.

61. Schroeder BW, Verhaeghe C, Park SW, Nguyenvu LT, Huang X, Zhen G, Erle DJ: AGR2 is induced in asthma and promotes allergen-induced mucin overproduction. Am J Respir Cell Mol Biol 2012, 47:178-185.

62. Zhang Y, Ali TZ, Zhou H, D'Souza DR, Lu Y, Jaffe J, Liu Z, Passaniti A, Hamburger AW: ErbB3 binding protein 1 represses metastasis-promoting gene anterior gradient protein 2 in prostate cancer. Cancer Res 2010, 70:240-248.

63. Maslon MM, Hrstka R, Vojtesek B, Hupp TR: A divergent substrate-binding loop within the pro-oncogenic protein anterior gradient- 2 forms a docking site for Reptin. J Mol Biol 2010, 404:418-438.

64. Kim JH, Choi HJ, Kim B, Kim MH, Lee JM, Kim IS, Lee MH, Choi SJ, Kim KI, Kim $\mathrm{SI}$, Chung $\mathrm{CH}$, Baek SH: Roles of sumoylation of a reptin chromatinremodelling complex in cancer metastasis. Nat Cell Biol 2006, 8:631-639.

65. Venteicher AS, Meng Z, Mason PJ, Veenstra TD, Artandi SE: Identification of ATPases pontin and reptin as telomerase components essential for holoenzyme assembly. Cell 2008, 132:945-957.

66. Rashid S, Pilecka I, Torun A, Olchowik M, Bielinska B, Miaczynska M: Endosomal adaptor proteins APPL1 and APPL2 are novel activators of beta-catenin/TCF-mediated transcription. J Biol Chem 2009, 284:18115-18128.

67. Qi D, Jin H, Lilja T, Mannervik M: Drosophila Reptin and other TIP60 complex components promote generation of silent chromatin. Genetics 2006, 174:241-251.

68. Bellosta P, HulfT, Balla Diop S, Usseglio F, Pradel J, Aragnol D, Gallant P: Myc interacts genetically with Tip48/Reptin and Tip49/Pontin to control growth and proliferation during Drosophila development. Proc Nat/ Acad SciU S A 2005, 102:11799-11804

69. Dong A, Gupta A, Pai RK, Tun M, Lowe AW: The human adenocarcinomaassociated gene, AGR2, induces expression of amphiregulin through Hippo pathway co-activator YAP1 activation. J Biol Chem 2011 , 286:18301-18310.

70. Ambolet-Camoit A, Bui LC, Pierre S, Chevallier A, Marchand A, Coumoul X, Garlatti M, Andreau K, Barouki R, Aggerbeck M: 2,3,7,8-tetrachlorodibenzo$\mathrm{p}$-dioxin counteracts the $\mathrm{p} 53$ response to a genotoxicant by upregulating expression of the metastasis marker agr 2 in the hepatocarcinoma cell line HepG2. Toxicol Sci 2010, 115:501-512.

71. Pohler E, Craig AL Cotton J, Lawrie L. Dillon JF, Ross P, Kernohan N, Hupp TR: The Barrett's antigen anterior gradient- 2 silences the $\mathrm{p} 53$ transcriptional response to DNA damage. Mol Cell Proteomics 2004, 3:534-547.

72. Imamura T, Hikita A, Inoue $Y$ : The roles of TGF- $\beta$ signaling in carcinogenesis and breast cancer metastasis. Breast Cancer 2012, 19:118-124.

\section{doi:10.1186/bcr3408}

Cite this article as: Salmans ML, et al:: The estrogen-regulated anterior gradient 2 (AGR2) protein in breast cancer: a potential drug target and biomarker. Breast Cancer Research 2013, 15:204. 
(a)

AGR2

(b)

AGR3

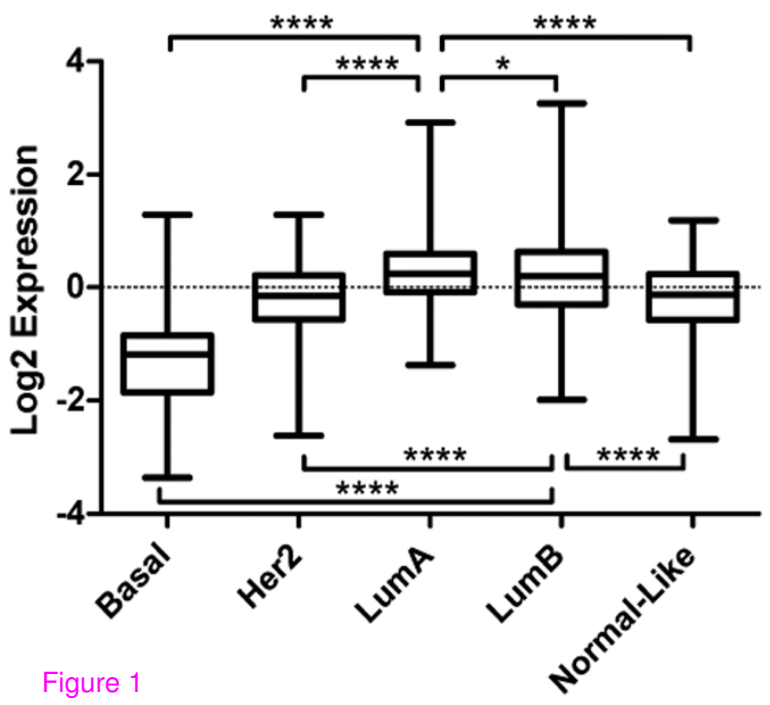

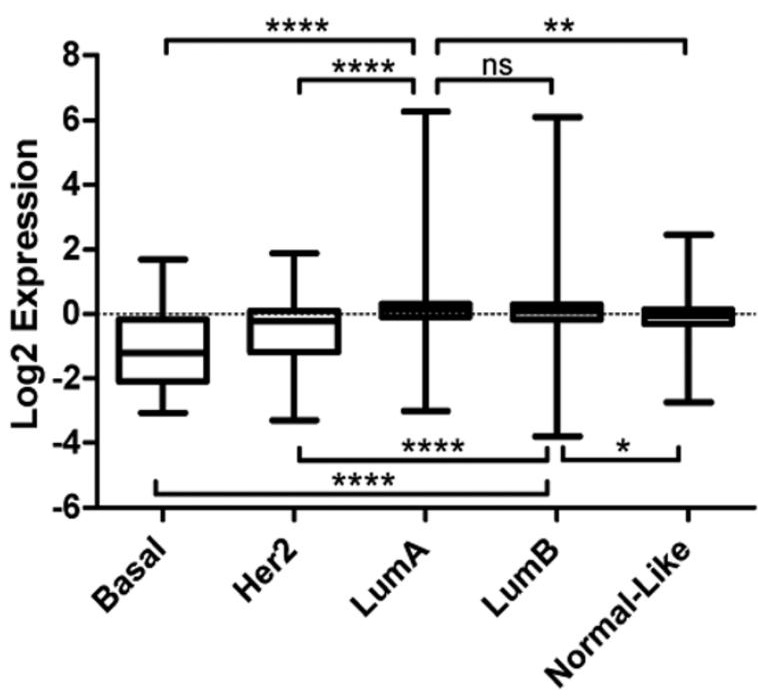


Window Position

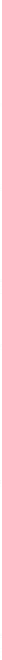

(b)

\begin{tabular}{|c|}
\multicolumn{1}{c}{ Key } \\
\hline - ERE \\
a 22 \\
c ER \\
\hline
\end{tabular}

Figure 2

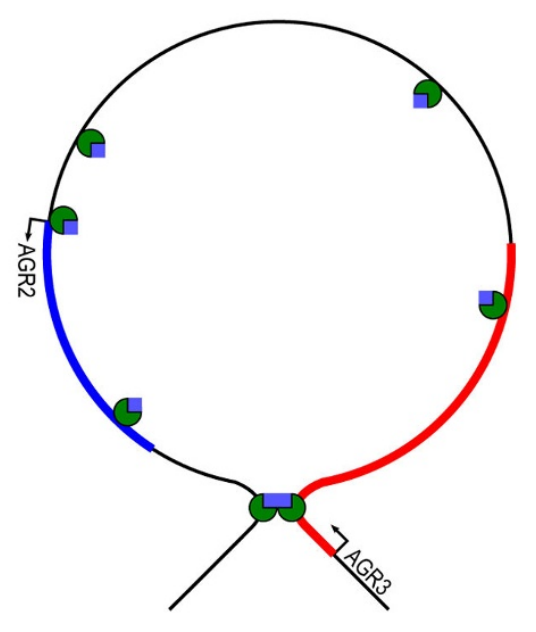

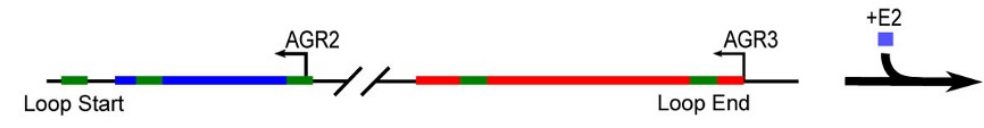
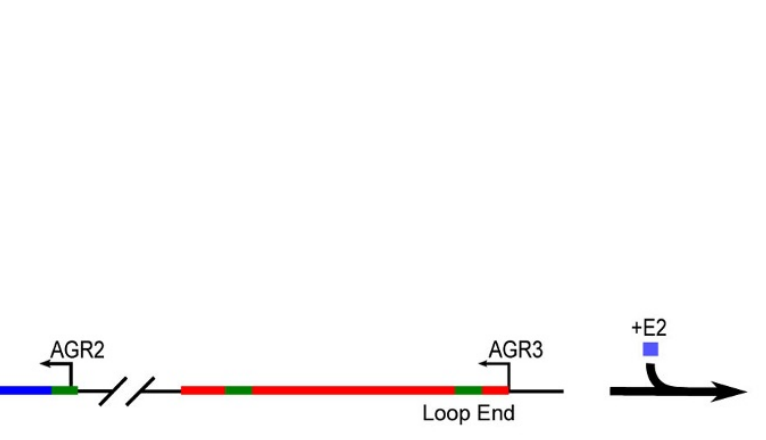

Loop End

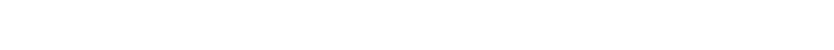

(a

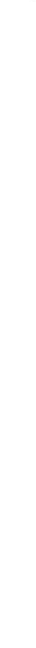




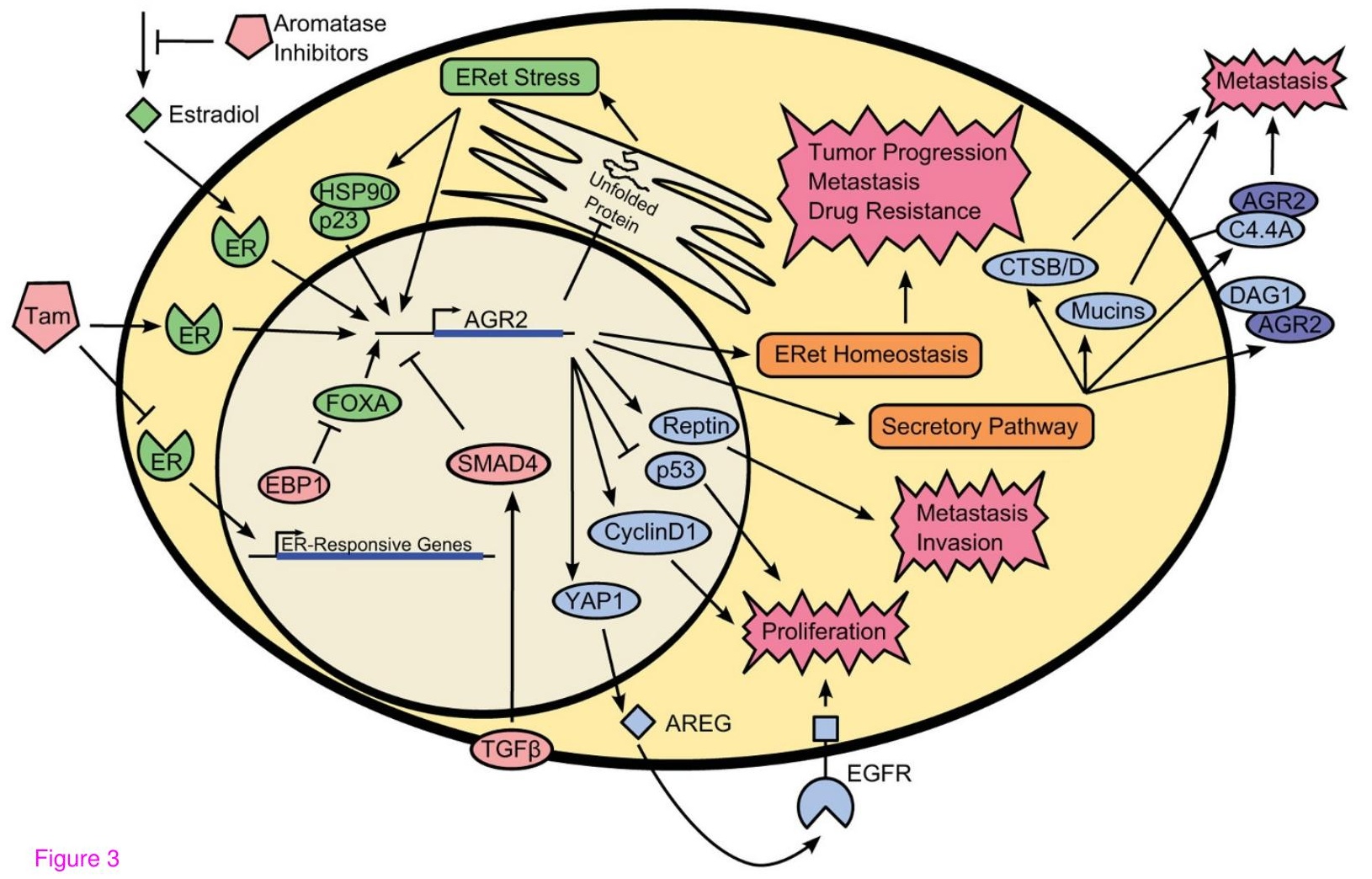

